\title{
DNAJB1 wt Allele
}

National Cancer Institute

\section{Source}

National Cancer Institute. DNAIB1 wt Allele. NCI Thesaurus. Code C122561.

Human DNAJB1 wild-type allele is located in the vicinity of 19p13.2 and is approximately $15 \mathrm{~kb}$ in length. This allele, which encodes DnaJ homolog subfamily B member 1 protein, is involved in the modulation of heat shock protein 70 activity. A chromosomal deletion that fuses this gene and the PRKACA gene is associated with fibrolamellar carcinoma. 